\title{
FEAR IN BORDER NARRATIVES: PERSPECTIVES OF THE FINNISH-RUSSIAN BORDER
}

\author{
Kirsi Laurén
}

\begin{abstract}
This study discusses the socially and culturally constructed FinnishRussian border which has been developed as a lifelong process, in the context of modern elderly Finns. It focuses on the emotions of fear represented in life and historically contextualised narratives discussing the post-war period in eastern borderlands. The included texts concentrate on border issues and are mainly based on the writer's personal experiences. The analysis is based on oral history methodology and highlights mainly the represented personal interpretations of the past, rather than actual historical events. The concept of fear is used as a theoretical tool to interpret the expressions of emotions in narrated memories. The study seeks to illustrate the causes of fear on the Finnish-Russian border in peacetime contemporary Finland.
\end{abstract}

Keywords: fear, Finnish-Russian border, experience, life-history, place

\section{INTRODUCTION}

The eastern borderline between Finland and Russia is the longest national border in Finland $(1340 \mathrm{~km})^{1}$. Today, a principal characteristic of especially the north-eastern and eastern border areas is sparse population. Over the last 40-50 years, settlements and job availability have been increasingly centralised around big cities, mainly in southern Finland's population centres. Nonetheless, many people who now live in different parts of Finland have spent their early life near the Finnish eastern border or in present Russian Karelia, which belonged to Finland prior to the Second World War (WWII). However, the memories of old borders and borderland landscapes remain in peoples' minds (see, e.g., Häyrynen 2006).

Among Finns, the fear of the Russian border and Russophobia have their roots in Finland's history and especially the events of WWII (e.g. Luostarinen 1986; Karemaa 1998; Vilkuna 2005; Lähteenmäki 2009; Raittila 2011). In 1939 the Winter War began with the Soviet Union's attack on Finland and the resettlement of evacuees from Finland's eastern border areas to western parts of 
Finland. Finland had to cede East Karelia, parts of north-eastern Salla, and the Kuusamo and Petsamo regions, together with the outer archipelago of the Gulf of Finland to the Soviet Union. In 1940 the war ended with a defeat for Finland, however, in 1941 the Continuation War started and, along with Germany, Finland attacked the Soviet Union and the occupied East Karelia region. During this period, the Karelian evacuees once again returned to their homes. When the Continuation War ended in 1944, Finland was obliged to give up East Karelia and the resettlement of evacuees from ceded territories resumed. Over 400,000 Karelian evacuees had to leave their lands and establish new homes all over Finland, and Karelia was never re-taken. The Germans were driven out during the war in Finnish Lapland in 1944-1945 and in the post-war period that followed, the Soviet Union sought to maintain a good relationship with Finland. After these dramatic wartime events, Finland's position was uncertain and for years its future appeared as if it would follow a path similar to that of the Baltic States and Poland. Finland, though, managed to avoid occupation and maintained its independence (Fingerroos 2012: 483-484; Laine 1999: 155-156; Kinnunen \& Jokisipilä 2012: 435-436; Meinander 2012: 49-50).

The roles of the Finnish-Russian border have varied a great deal, and this has reflected in Finnish culture and everyday life in the border regions. Undoubtedly, the fearful experiences of WWII have scared people for life on both sides of the border. During the Soviet period and after the war, the border between Finland and the Soviet Union was strictly guarded and almost impossible to cross. Today, the Finnish-Russian border is utilitarian and there is more interaction and transnational movement than in the period of the Iron Curtain. However, the border still exists and is distinct. It separates territories and two states. As such, this borderline has an influence on cross-border and cultural contacts because territorial borders are always boundaries for other territorial entities (Paasi 2000: 89).

My study discusses everyday experiences relating to the Finnish-Russian border in the narratives collected in an open writing collection campaign organised in today's Finland. These life-historically contextualised border narratives mainly concern elderly Finns (mostly over 60 years old) and their experiences and conceptions of the Finnish-Russian border. By border narratives I mean the texts that reflect the characteristics and functions of borders from the perspective of a micro-level (see Pickering 2006: 45). These border narratives are written by women and men who live (or have previously lived) near the Finnish side of the Finnish-Russian border or who have visited such regions. The texts were written in 2010 , yet the time span reaches back to the 1930 s when the oldest writers of the narratives were still children. 
The aim of the study is to figure out how elderly people living near the Finnish side of the border write about their relationship with the border, and how they make sense of their border-related lives in their narratives (Doevenspeck 2011: 129). I take into account especially the sense of fear which is represented in these personal texts. Fear is a strong feeling and it is not the only emotion represented in the studied texts, and nor is it an emotional state that dominates the narratives of contemporary experiences of the Finnish-Russian border. Yet, in the different texts of the research material the representations of fear emerge so often and in such various ways that they deserve closer examination. Consequently, the central research question is: Why do elderly Finns (mainly from Eastern Finland) feel fear of today's Finnish-Russian border?

In their narration of different themes regarding their everyday life on the border, people express experiences, values, concerns and ideas that are important to them as individuals or as collectives (Klein 2006: 14). People's narratives expand our understanding of borders and bordering practices beyond institutional discourses (Prokkola 2009: 21). Border narratives bring out viewpoints on past events and their subsequent consequences that do not necessarily follow the official history or political discourses. The texts studied in this article represent an oral history ${ }^{2}$ that reinforces publicly shared grand narratives and, in addition, buttressing counter-narratives (Bamberg \& Andrews 2004). My approach to border narratives is experience-centred, by which I mean that the analysis rests on a phenomenological assumption that through a narrative or story, experience can become part of consciousness.

The personal and experience-centred border narratives of this study constitute oral history in written form and they are narrated in a life-historical context. Studying memories and oral history brings out interpretations of the past from the viewpoints of those 'below', such as marginal groups, defined social classes, women, children and isolated people (Fingerroos \& Haanpää 2006: 27). The focus is on the so-called common people and on how they understand and remember past events, how they experience events and what meanings they give to their experiences (Jaago 2006: 1). Oral history is special because it tells more about the meaning of past events than the actual events themselves (Portelli 2006: 55). Therefore, the significance of oral history and the life-historically written personal narratives of border experiences are in their place in the history of a particular life, community and society (see Bornat 2002: 42).

Narrated memories of everyday life at borders are considered as representations of places; the places of the border area. Consequently, the concept of the place and its associations to reminiscing and oral history are essential in this study. Together with place, reminiscing and oral history, the concept of fear constructs the theoretical framework of this study. The framework is introduced 
in subsections. Research brings forth the writers' viewpoints and examines the deep structures of the texts such as cultural meanings and textual cues, which highlight the author's emotional representations. Similarities and differences between the texts were considered, as well as text styles and word choice of the subject. The comparison of the similarities and differences between the texts helps to reveal the inner meanings of fear.

\section{REMEMBERED PLACES AND EMOTIONS}

Along with personal and collective ideas, border narratives are also representations of places. Thus, places like borderlands constitute an existential phenomenon, and not merely geographical objects (Relph 1996: 906). Places are not just static, they are processes - this can be taken to mean that places can be conceptualised in terms of social interactions, both local and those that stretch further afield. Thus, every place is a unique mixture of the relations that configure social space (Massey 1994: 155; Massey 1995: 59-61). Places are infused with meaning and feeling, and the way people feel about places indicates the various senses of that place. The meanings given to a place may be so strong that they become a central part of the identity of the people experiencing them (Rose 1995: 88-89). Most human experiences and memories are based on places and therefore the place - for example a border - refers to a micro-level world of meanings (Heimo 2006: 50).

Giving meanings to different things and places is a lifetime process. Every new experience is based on the past and that is why remembering is so important in processing both personal and social life in the borderland setting. Memory and recollection are in a central position when identifying with communities and cultures. Communities use these faculties to introduce and familiarise new arrivals with the community's collective past in order to help them to identify themselves. Such memories are often organised around places and objects (Misztal 2003: 15-16). The sense of fear of the Finnish-Russian border that emerges from the written memories of elderly Finns tells us not only about the authors' personal pasts but also their oral histories, so both the written form and the authors' life histories become the places of memory (see Portelli 1994: 61).

By reminiscing, the memories naturally intertwine with emotions. Typically, individuals often remember emotional events more than the non-emotional, and positively and negatively perceived events are more likely to be remembered than neutral ones (Kensinger \& Schacter 2010: 602). For example fear, hate, and falling in love are strong emotions and strong emotions linked to the meaningful episodes in life are hard or impossible to forget. The reminiscing 
and narrating, for instance, of pleasant or frightening things and specific life situations can spark off either positive or painfully emotional memories. Also, asking about certain things can trigger emotions in the subject that has been covered up (Kaivola-Bregenhøj 2003: 336-340).

\section{THEORISING THE CONCEPT OF FEAR}

Emily Hicks (1993) has stated that "border culture includes a deep fear, the fear of being seen/caught/asked for identification". Border culture is a strategy for facing fear and also demonstrates a will to deconstruct the language of representation, stereotypes, imitation, and violence (ibid.: 40). Hicks's statements are undoubtedly justified especially when trying to cross a border that is strictly guarded and not open or easily-crossed, especially for those without legal protection. The emotions of fear and contrary senses of security are also familiar to people who live their daily lives near national borders.

The sense of fear rises when we feel uncertainty and are ignorant of the threat we are facing. Many things can be perceived as frightening or threatening, for example violence, disaster or disease. People have different senses of fear and produce different reactions to them - one such reaction is to face the threat and veer between the alternatives of escape and aggression. Humans also have a socially and culturally 'recycled' or derivative fear that guides their behaviour, whether or not a threat is immediately present. This kind of fear is a sediment of our past experience of facing the menace directly. As Zygmunt Bauman (2006) says, this "sediment outlives the encounter and becomes an important factor in shaping our conduct even if there is no longer a direct threat to life or integrity". Derivative fear is the sentiment of being susceptible to danger - it is a feeling of insecurity and vulnerability (Bauman 2006: 2-3). In spite of fear's negative quality, it is a defensive feeling; it prepares us to react to threat and makes us able to function if needed. The feeling of fear evokes a need to avoid threatening occasions whether they are physical, mental or social. The sensibility to feel fear depends on both innate reasons and past experiences (Turunen 2004: 127).

Different eras pose different threats and different fears elicit different responses (see Bourke 2005: 6-7). Dangers can be concrete, real or imaginary. Often people feel fear, even though what may possibly constitute a danger may have little potential to be actually realised. Thus, fear is a condition of possibility (Furedi 1997: 15; Massumi 1993: 12). Nevertheless, the individual feeling of fear is always real. Whilst there are instinctive fears that most people share, there are also fears that are socially imbibed within cultures, from generation 
to generation. Historical events like wars, environmental or financial catastrophes and accidents, form part of the collective memory so that people are more or less aware and provide for such kinds of possible threats and dangers in the future. For example, WWII remains one of the most threatening incidents in Finnish collective memory, and especially for the generation who lived during the war and the immediate period that followed.

In this article, fear is understood both as an individual state and as a social and collective experience. The physical and social dimensions are fundamentally intertwined in fear and this means that the fear of spaces and places is produced in the social process and, in addition, the relations of social power lie behind the perception of fear. Certain places provoke feelings of fear more than others. There are people and groups who seek to control such fear and there are those whose lives are pervaded by it. Accordingly, fear has material dimensions that are worth taking into account (Koskela 1999: 2; Pain \& Smith 2008: 12).

We often maintain that the opposite concept of fear is security. Consequently, security implies that you are free from fear and threat, and/or you are capable of fighting against such threat. People usually have particular kinds of threats in their minds and they use the term 'security' in the context of these threats (Baldwin 1997: 15). Accordingly, in the border narratives of this research, fear is dialogically constructed with the sense of security.

\section{BORDER NARRATIVES AS RESEARCH MATERIAL}

The research material consists of selected texts gathered from open writing collection entitled Living in the Borderlands - Experiences of Everyday life at Borders. ${ }^{3}$ This nationwide enterprise was organised by the Finnish Literature Society (FLS/SKS) and the Writing Cultures and Traditions at Borders research project in $2010 .{ }^{4}$ This open writing collection was premised on gathering material, in the course of which voluntary contributors sent their written experiences and memories to the organisers. Writing collections are common in Finland and different $\operatorname{archives}^{5}$ have focused on this activity. Usually, ordinary people are asked to write about their experiences of various themes and it is typical that people respond to these collections by writing about their experiences in a life-historical context (Latvala \& Laurén 2012: 126). Before responding to an anonymous reader or researcher, authors have to decide which specifics and episodes of their personal life they dare to reveal. The type of narrative people finally decide to contribute naturally depends on the questions posed and the writers' trust in the researcher involved. 
The Living in the Borderlands writing collection was targeted at the general public. The call for contributions was sent to the Folklore Archive's correspondents, about 200 people living all over Finland. The invitation was also distributed among several local newspapers in the east of Finland. People were asked to write about their experiences and daily life in the borderlands: What is everyday life like in the borderlands? Write about your own experiences. In the call for contributions, some themes were mentioned to help people recall their memories and to motivate them to write. Accordingly, the list of various themes functioned as a catalyst for reminiscence work (see Howarth 1999: 44). The themes mentioned were: cross-border contacts; the way of life and traditions on borders (past and present); borderlands in the eyes of children and young people; dwelling, working, school and studying on borders; fears concerning national borders; local perspectives on wartime; nature in the borderlands; trespassing and crimes at borders; importing groceries and goods; language issues on borders. ${ }^{6}$

Altogether, 36 people ( 22 women and $14 \mathrm{men}$ ), participated in the collection and sent 271 pages of unpublished text. The collection also includes nine photographs, two CDs, and two author's editions. Some authors sent two or even up to four different stories. The age of the writers varied between 50 and 91. Almost two thirds of the participants were born before or during WWII, thus, many of them were retired. Most of the authors were from North or South Karelia, and in consequence, about three quarters of the stories deal with the eastern border between Finland and Russia. ${ }^{7}$ The authors represent various social backgrounds and occupations such as farmers, nurses, teachers, border guards and office employees. The collection Living in the Borderlands is archived at the Joensuu Folklore Archives of the Finnish Literature Society.

The collection focused on personal life and experiences. Even though it did not ask people to write life-historically, they did so and consequently the research has a life-historical and partly biographical context. Nonetheless, this is not a traditional biographical research which typically starts with an interviewer's broad request to interviewees to tell their whole life story (Rosenthal 2007: 49). In spite of the more restricted thematic emphasis (see previous page) people spontaneously started their narration by telling about their childhood and the years following it, intertwined with the border themes presented. Thus, a common narrative structure in these texts includes a distinction between past and present, and the ideas of future hopes and fears. A chronologically ordered life-historical series of experiences usually constructs quite a coherent story. People use this approach to tell more or less of their personal experiences and, consequently, about their emotions. It is typical in such cases that the closer the theme is for the narrator, the more emotional their story becomes. 
The topics mentioned in the writing invitation obviously had an influence on the themes of narrated stories; they became a type of instrument of memorisation. The whole collection includes various themes, for example war time memories, narratives of crossing the border and author experiences of travelling in the Soviet Union and present day Russia. Many of the stories touch on the wartime, the evacuations during WWII and the fears and contradictory emotions concerning the proximity of the eastern borderline immediately preceding, during and after WWII. During wartime, the writers were either small children or had not yet been born. So, the authors recount their very early memories or memories heard from relatives or friends. Many of the stories are family narratives that combine the appropriation of both historical and remembered events ("As a child I was there"; "My mother and father were there and they said that...") (Portelli 2003: 6-7). Typically, these memories are of wartime experiences and how the war appeared through the eyes of the children or their parents, relatives or neighbours living near the Russian border.

It is quite obvious from the texts that the war was terrifying and many have negative and unforgettable memories of it, especially of the frightening Soviet enemy. But it is interesting that even today, many decades after the war, the sense of fear is prominent and comes up quite often in people's narratives. Regardless of not having lived during the wartime, many people living near the eastern border today recount the same feelings as those who had personally experienced the war. So, the feelings are probably partly imbibed from other people but also felt both individually and concretely in today's everyday life. Of course many cultural and social aspects such as school teaching, written history, media, literature and art have influenced peoples' minds, their attitudes and emotional states. So, along with many kinds of personal memories, the stories in the Living in the Borderlands collection also include heard and/ or read stories related to WWII.

My analysis places emphasis on those narratives that highlight the sense of fear, especially in the post-war period. I have chosen 20 texts from the corpus narrated, written by 11 women and 9 men born between 1921 and 1949. Thus, the writers are relatively old, with the youngest of them being over 60 and the oldest almost 90 years old. The selected essays cover the writers' personal experiences but also include the stories and experiences heard from other people.

All the following text examples are from the Living in the Borderlands collection. The page numbers of the text examples (archive sources) are given in parenthesis. 


\section{DREAD OF BORDER AND THE SOVIET ENEMY}

The country [Russia] stimulates, frightens - there were lots of beliefs and stories about it. (Woman born in 1931, Living in the

Borderlands, 2010, p. 38)

As the example above shows, fear is an emotion that often arises when elderly Finns write about their everyday life on the Finnish-Russian border. Authors write about the period of WWII in Finland and the sense of fear that prevailed, even long after the war had ended. Narratives tend to start by remembering a period of early childhood and adolescence, which take the aged writers' minds back to the wartime or to the stories they have heard of it. Near the border districts, the fear of the enormous Soviet enemy is described as a fear of death. Some parts of the narrated emotions reflect the atmosphere that prevailed among the family members or in the village community before, during and after WWII. Authors have heard their parents, relatives and other people's stories concerning the past events and the values implicit in the ethos of those days. By telling and retelling the heard stories and accounts of everyday life on the eastern border, the writers simultaneously unburden their strong emotions, and, in addition, their thoughts concerning the Russians. Accordingly, strong emotions like fear and the stories they have heard are carried from one generation to the other (see Latvala \& Laurén 2012: 131).

During WWII the Finnish war propaganda also constructed an anti-Soviet atmosphere by presenting a terrifying snapshot of the Soviet Union. This propaganda has undoubtedly had an influence on people's conceptions of their eastern neighbour (Luostarinen 1986). During WWII and immediately after, the fear of a terrifying enemy was familiar to people on both sides of the border; the Finns were afraid of the Russians and the Russians were afraid of the Finns (Brednikova 2000: 27-30; Rainio 2009:135-138; Hakamies 2012: 96-100). Even today, Russia has a special role in the Finnish defence policy and is considered to be Finland's potential enemy; yet, it is potential in the sense that there are no actual hostilities between the two countries (Moisio \& Harle 2002: 35-36, 53).

In the research material, the theme of fear of the eastern enemy comes out repeatedly. The oldest authors still remember the events of wartime, such as the evacuations, the sound of warplanes, the boom of cannons and the tragic messages they received of relatives who had died on the battlefield. Everyday life near the eastern border was felt to be chaotic and frightening in many ways, as it was also in other places in Finland. As a result of the war, hundreds of thousands of Finnish people from Karelia (eastern Finland) and parts of northeastern Finnish Lapland had to move to other parts of Finland. Many important 
cities like Sortavala and Viipuri in the Karelia region were ceded. This awakened negative emotions and enormous sorrow, especially among the ones who had to leave their home districts for good. ${ }^{8}$ For example, a 69 -year-old man who lived in South Karelia throughout his childhood, notes: "The new border that mutilates and amputates Finland, aroused impotent rage especially among people who lost their homes and birthplaces." (Living in the Borderlands, 2010, page 176)

WWII radically changed the Finnish-Russian border, both regionally and nationally. The new border was agreed upon in Moscow in 1944 and obliged both Finns and Russians to adapt to the situation (Kosonen \& Pohjonen 1994: 360), but at the micro-level in Finland it is thought that the whole war and its losses were both a terrible wrong and a national disaster. The Soviet troops fighting against Finland, lost relatives and relinquished territories were felt as an insult against Finland's national and military self-esteem and against its cultural integrity. The lost regions remind the Finns invariably of the fear of bereavements, the danger of war and the dread of becoming part of a big eastern empire. To be swallowed up by this empire was at the time and still is the worst thing many can imagine transpiring. Threatening discourses which revolve around these frightening pictures are accepted quite unanimously within the national canon. Especially, the issues of the lost Karelia regions have, until recently, been an emotive and active subject of discussion. In consequence, for many Finns, Russia still represents otherness (Lähteenmäki 2009: 432-433; Fingerroos \& Loipponen 2007; Fingerroos 2012: 30; Kangaspuro 2012: 50, 69).

WWII is a meaningful part of elderly people's life-histories and constructs nationally one of the most significant culturally shared narratives. This narrative appeals to sentiments - it is part of Finland's history, and this sentiment can also be seen in the post-war narratives of the research material. Fearful emotions have weighed heavily on people, especially those who lived near the border. As such, even in a peacetime period as late as 2010, the memories and visions of those involved were clear. For example, when describing her wartime fears, one 89-year-old lady writes: "I remember everything like it was yesterday" (Living in the Borderlands, 2010, p. 15).

After the war and during the Soviet period when the Finnish-Russian border was strictly guarded and hard to cross, people felt an invisible threat, and in their visions the threat came always from the eastern direction. Along with memories of war, one of the things that can be seen to cause negative emotions against the eastern border is the long period of the Iron Curtain. It was a period when the Soviet border was practically closed. There was little or no social intercourse between ordinary Finns and the Soviet people who lived in the border district. In consequence, the nation behind the border became unknown and forbidden; Finns and Russians were neighbours without know- 
ing each other. They were spatially near to each other but remained isolated because of the guarded border. When these people on both sides of the border were not allowed to spontaneously engage with each other, there was little interest to build any relationship, not to mention making friends. If at the time they knew little of what the neighbours in the neighbouring country were doing, what kind of life they led or what could be expected of them, it would be difficult to feel any affinity towards them. Rather than to trust and feel secure, it was perhaps easier to imagine that the unknown neighbours were up to no good (Furedi 1997: 127-128).

In post-war border narratives, the clearest memories the Finns had of the Russians connect to the fearful memories of war. The narratives highlight how people were at all times prepared for the worst - to protect themselves against the eastern enemy. Negative attitudes to the eastern neighbour can be seen in elderly Finns' post-war narratives. When the authors reminisce about their childhood, they admit that they did not quite understand why various acts on the Soviet side of the border aroused suspicions and caused fearful reactions among adults.

On one occasion when we were looking out of the kitchen window over the dark winter evening, there were flares soaring straight into the sky. Father sighed in passing that the "Vanjas' [Russians] have something to say, once again". In those days I did not ask more about the flares, and there were no explanations about them, but there was something frightening in them. I understood that it was not a question of fireworks that Mother had read about in a paper. (Woman born in 1947, Living in the Borderlands, 2010, p. 193)

Even though Russia is geographically next to Finland, many Finns have never visited the former Soviet Union or present-day Russia. According to border narratives, the eastern neighbour has often been placed as mentally distant from Finland (Latvala \& Laurén 2012: 131). In addition to war memories, the writers base their images of the Soviet Union and Russia mostly on heard stories, news, movies, literature or other second-hand sources. Ordinary Russians are still felt as strangers although more and more Russian tourists visit Finland (especially the eastern part) every year. The narratives of elderly Finns' first post-war contacts with the Finnish-Russian border tell of suspicions and curiosity. For example, there is a narrative of a woman who lived 30 years abroad and moved back to eastern Finland during the 1980s. She recalls that in those days she and her foreign friends based their images of the Soviet Union upon western action movies and literature: 
The border created a kind of mystique to our lives because it was so near. All our foreign visitors were taken somewhere to the hills of Tuupovaara where the great Soviet Union could be seen far away across the border. The images of the Great Russia were based on our visions co-opted from some James Bond films or some other spy novels. (Woman born in 1943, Living in the Borderlands, 2010, p. 29)

When the Soviet Union collapsed at the beginning of the 1990s and the border gradually opened, people felt that something miraculous had happened; finally it was possible to see what lay behind the mysterious eastern border. This aroused confusing and very touching emotions among people on borders: "That moment in Värtsilä border station kept my eyes moistened", depicts a 63-year-old woman from Värtsilä, northern Karelia. (Living in the Borderlands, 2010, p. 193)

\section{FEAR AND DEFIANCE AGAINST RUSSIANS}

Immediately after the war many people in Finland did not accept the new border, and seditious ambience among local border people was not unusual. In people's minds it was inconceivable to have no possibility to visit earlier home districts, important cities and villages, even though they were so close behind the border. On the basis of the border narratives, most of the border people respected the official restrictions on the border zone, although some people used to express opposition to the rules and cross the border without the required special permission, even though it was a penal offence. Undoubtedly, forbidden border crossings were frightening but it was a way to brave the threat and express dissidence in a helpless situation, as this example shows:

At the beginning of the 1960s, one kind of sport for village idiots in Närsäkkälä village in Kitee was to go to Russia [the Soviet Union] along the old straight road or along the frozen Lake Pyhäjärvi, as if the land behind the Russian border belonged to us [to the Finns]. Before the war there were close relations with Sortavala. Sortavala was the city of Kitee dwellers where they ran their important errands. It was only 30 kilometres from Närsäkkälä to Sortavala. (Woman born in 1949, Living in the Borderlands, 2010, p. 36)

Since the 1960s (and especially since the 1990s when the Finnish-Russian border opened up), border crossing has constantly increased and today there is a vivid interaction. The Finns, for example, visit their old home districts in the Russian side of Karelia, they work in Russia, and go shopping there. Intermarriages 
are quite common as well. Similarly, Russians come to Finland for shopping, working, and, in addition, to buy land, houses and summer cottages. These last-mentioned issues are something that arouse contradictory emotions among elderly Finns. During the last decades, many Russians have bought houses and plots in Finland. The National Land Survey of Finland has estimated that there were over 500 related transactions in the course of 2011, and it is estimated that Russians own Finnish land to a value of over hundred million euros (Taloussanomat, November 17, 2011). Russians bring financial welfare to Finland by buying land and buildings, but at the same time in Finland this activity stirs up a kind of suspicion, fear and anger towards them. It is suspected that Russians are once again trying to take over the Finns' domains and even though the Russians in today's Finland mainly represent a new generation who have nothing to do with the actions of the Soviet Union during WWII, their presence and acts in Finland arouse suspicion and anxiety among elderly people. Fearful memories and the conceptions of war are vivid, traumatic and they are actively maintained and handed down from one generation to the other. The following text illustrates some elderly Finns' negative attitudes to Russians in the city of Imatra in South Karelia, from the 1960s to 2010:

Tourist and shopping tours from the Soviet Union to Finland, and plenty to Imatra, started as well. In the beginning, rumours unfolded against Russians, rumours of dangerous and impudent Russian tourists. There were talks about ready-made graves on the roadside, etc. These rumours stopped quite quickly but anger against Russians still persisted. The anger has increased along with the Russians' trades of land and summer cottages. Many people still resent the loss of Karelia. There is anger against Russian tourists even though they bring money to Imatra. (Man born in 1927, Living in the Borderlands, 2010, p. 261)

As the writer above notes: "Many people still resent the loss of Karelia". Russians were long associated with ruthless killing and death ("ready-made graves on the roadside"), although as the writer notes, the stories were just groundless rumours. Several border people mention in their narratives that sometimes they were afraid of illegal trespassers, and one writer relates a fearful experience of a Russian defector who thrust their way into her home. Today's fears are somewhat different than those of the earliest decades after WWII, as the threat of a new war is not a current topical issue. Nevertheless, inconsistent attitudes towards Russians are still alive, as can be seen in the descriptions of elderly peoples' narratives concerning land trading to the Russians. The border is now so ordinary that it is not even featured in daily life but the selling of 
land to the Russians frightens and arouses helpless feelings in the narrative writers because "money has got power". A woman from South Karelia notes:

It is no longer remembered that the border is so near. The border guards are vigilant and helicopters fly over the border from time to time. Nonetheless, at least when dark comes, I lock the door. I feel bad to hear again that some people have sold their houses to the neighbours [to the Russians]. Big money has power. (Woman born in 1930, Living in the Borderlands, 2010, pp. 206-207)

Traumatic memories, the heard and imagined stories of Russians and strong emotions have long-lasting effects on the personal and collective memory. For example, often experiences of a fear of death or helplessness make people feel that they are somehow different than before. Traumatic events and the time of recovery stay permanently in both the individual and collective life course (Aarelaid-Tart 2006: 35). Consequently, among elderly Finns the senses of fear and suspicion against Russia continue to some degree.

In this connection it is worth remembering that in Finland during the period of Finlandisation ${ }^{9}$ (1968-1982) it was not appropriate to speak freely or negatively about the Soviet Union and past wartime memories. As such, in public discussions even traumatic war experiences remained in the background. During recent decades in Finland, it has been allowed to discuss freely and publicly the memories of WWII and the relationships between Finland and the Soviet Union and present-day Russia. Additionally, it seems important for elderly people on a micro-level to write about their negative emotions.

\section{FEAR AND SECURITY IN REMOTE BORDERLANDS}

Fearful emotions are also typical in the Living in the Borderlands' narratives which tell about life in fringe areas near the eastern border where people share their living environment with predators such as bears and wolves. The fear of animals is different to the fear of people, other cultures and nations, yet the narratives of facing fearful animals in border areas represent emotions that are relatively typical in a borderland environment.

When thinking of the natural habitats of predators we are accustomed to perceive them as being different to human environments. Cultivated fields, gardens and man-made buildings are the familiar and humanised world and the forest surrounding seems as a counterpoint to these cultivated environments of towns and cities. Especially during periods of urbanisation, the forest is envisaged as being infested with outlaws, wild animals, robbers, witches, and 
demons (Tuan 1979: 81). For Finns, the images of the forest originate from the time of a hunting culture when the word forest (metsä in Finnish) also had the meaning of a border, fringe or edge. According to ancient Finnish myths and oral poetry, the forest was inhabited by spirits and powers of the hereafter and was to be treated with caution and deference. The most respected and largest animal in this environment was the bear. The interaction between humans and bears and the exercise of a bear cult has long traditions in Finland and has widely spread among hunting cultures in Northern Europe, Siberia and North America. The bear was a mythic totem animal and the funeral feast of the bear was held as a sacred ritual. Later on, as the agrarian culture spread, forests were exploited and because of the small number of available meadows, cattle often grazed in the forests. Since that period, the bear and the wolf have been regarded as natural enemies of people as they ravaged the cattle (Apo 1997: 46-49; Klemettinen 2002: 144; Sarmela 2006).

Today, the eastern fringe areas near the Finnish-Russian border are mostly rural countryside and people are still living near nature and forests. Predators thrive in the remote wilderness and they do not recognise national borders. Local residents are adjusted to this coexistence with predators, although the people who spend their time in forests (e.g. hunters, berry and mushroom pickers, and hikers), are sometimes afraid of them. The bear especially is thought of as frightening (Palviainen 2000: 77-87). The border narratives speak about being frightened of meeting bears and wolves near home districts. The next text example illustrates how the stories of being afraid of predators describe the relationship between humans and animals and also the life in borderlands situated in the middle of wilderness and on the edge of human environments:

My images of the borderland interlocked with wolves, bears and all possible predators. [---] I remember that even in our home district, further from border, we were afraid of wolves. During at least one summer we took our cattle indoors, out of reach of wolves. I remember being scared to death many times when early in the morning I walked through the dark winter woods to the bus stop. Accordingly, in my mind, the first strangers coming across the border were wolves. Extremely frightening and cruel. (Woman born in 1949, Living in the Borderlands, 2010, p. 36)

In the narratives, the borderlands seem to symbolise something wild and unmanageable (extremely frightening and cruel). In this context it is noteworthy to highlight that in political discourses the bear has been used as a metaphor for Russia and the Soviet Union (see, e.g., Moisio \& Harle 2002; Tarkka 2012). So, in border narratives, predators (and especially the bear) can be interpreted as having an ambiguous meaning. 
It is an undeniable fact that sparsely populated borderlands are inhabited by predators that sometimes stray into people's territories. Contrary to the people living in marginal areas, people living in big cities and urban centres do not expect to face predators when they go out of their homes. In these borderland areas, however, encountering bears, wolves and lynxes is a genuine possibility. Such predators have always been part of everyday life in the remote countryside, even though they usually remain out of sight of people. Human control over these forest animals is restricted (or sometimes just impossible), and that is why border people feel the need to be prepared to face them in daily life.

Especially during the elk-hunting season in autumn, the newspapers in the east of Finland carry stories of hunting hounds being mauled by wolves. Sometimes bears enter people's gardens to eat apples, garden berries, cattle, sheep or dogs. In the countryside, people are often afraid of bears and wolves that might come too close to their homes. For example in the North Karelia border district, between 2000 and 2010, extensive damage was caused by predatory animals and even now people feel that carnivores are a real threat particularly to their children, for example, on their way to school. Consequently, the question of a feasible amount of wolves and bears arouses plenty of controversy both locally and nationally, culminating between the hunters and nature conservationists and also between the residents of the cities and the countryside (Rannikko et al. 2011: 30-39).

The frontier zone is an exceptional place to live because of its special restrictions concerning access and trespass. Official border guards administer security along the Finnish-Russian frontier zone. A long-time resident of the Finnish-Russian border writes about the border people's relationship to border:

It seemed good to us; it was a safe place to live because later on the border guards passed by our house even two times a day. [---] The border was felt as ordinary, we were not afraid of it, we got used to it. (Woman born in 1939, Living in the Borderlands, 2010, p. 171)

The example above is written by a woman who says that after WWII, her childhood home was situated in the frontier zone and was only 500 meters away from the border. For some time after the war, border soldiers and guards used to live in their home, even though the home was small. The border zone had its pros and cons. It was not allowed to take photographs in the direction of the border and every person over 15 years old had to have a residence permit. If visitors like relatives were expected, the border guard detachment had to be notified beforehand. The writer says, however, that living in the border district aroused a sense of security ("it was a safe place to live"). The state authorities 
were trusted, especially the border guards and the police, and she mentions that "we were not afraid of it [the border], we got used to it".

The impression described above is quite common among people who have lived near the border for a long time; yet, elderly border people also say that their relatives or friends from other parts of Finland or from abroad are usually afraid of the Finnish-Russian border. Border people seem to be used to giving reasons for their sense of security, which are marvelled at by other people. The everyday experiences of the border district and trust in the Finnish border guards, however, smoothes away the possible sense of fear - or at least leaves it in the background.

After WWII, many people in the eastern part of Finland found the new Soviet border tangibly more close to their homes than it used to be before the war. As time passed, people became accustomed to the nearness of the eastern border and their earlier sense of fear slowly subsided. The presence of Finnish border guards had a remarkable influence on the border inhabitants' adaptation to the new considerations of border regions. In the narratives, elderly people say that they feel safe when living near the guarded border, as no one can come near their home without somebody noticing. Finnish border guards are valued highly in the narratives and they are trusted to protect those living near the national border. Especially during the Soviet period, local Finns near the eastern border gained many types of assistance from the Finnish frontier stations and border guards. As the border guards had their eyes on the border zone, they took care of both national security and that of the local inhabitants. Gradually, the sense of fear shaded into a sense of security.

In the early times we felt as if the border was securing our safety. People living elsewhere wondered how we even dared to sleep so near the border. We knew that the border was closed and the border guards were watching over the border. There were policemen in the Vainikkala frontier station. There was even no need to lock the doors during the night-time because criminals avoided borders. (Woman born in 1932, Living in the Borderlands, 2010, p. 41)

The tasks of the border guards are numerous but during recent decades they have changed more than ever. Finland signed the Schengen Agreement in 1996 (with implementation in 2001), and joined the EU in 1995. In consequence, cooperation with the EU increased further and the education of border guards in Finland was integrated into the programme coordinated by the EU (Warsaw). The purpose of border surveillance is to maintain order and security and, in addition, border guards must have the knowledge and capability to undertake criminal investigation and leadership (Pohjonen 2009: 86-87, 167-169; The 
Finnish Border Guard, January 4, 2012). In 2009 the law changed so that, if the police are not available to perform urgent duties immediately, the border guard detachment may supplement them. The leading regional newspaper Karjalainen in North Karelia wrote in its editorial at the beginning of 2012 that today border guards are, aside from their main duties, invaluable in performing police duties, such as traffic control. As they have competence to undertake police duties, to administer first aid and have rapid response capability, they are essential for local residents in sparsely populated border regions, where it could take a long time to get the ambulance or the police (Karjalainen, January 4,2012$)$.

\section{CONCLUSION}

I have tried to demonstrate the micro-level approach to the Finnish-Russian border by concentrating on the life-historical border narratives of elderly women and men mostly from contemporary eastern Finland. The research focuses on their written representations of fear that seems to be one of the most repeated themes in their narratives. By reading the narratives side by side I noticed that different writers share each others' experiences and assumptions. Fear is connected to their personal and culturally shared knowledge of the Finnish-Russian border and the historical events relating to it, especially WWII. Memories of war and the fearful experiences of it are tightly stuck in elderly people's minds. In contemporary life, the remembered fearful emotions still have an effect on their attitudes and interpretations concerning the Finnish-Russian border and the Russians themselves. In addition to personal experiences, their social life, interaction, the stories heard from the others and the media have an influence on people's attitudes. However, today border people live their daily lives and give no special attention to the nearby national border, and the sense of fear no longer dominates their everyday life. On the other hand, however, reminiscing and telling of their fearful memories of the eastern border and the threat of the Soviet Union is obviously an important issue for them, and is partly a way to offload traumatic and fearful memories.

Many Finns (including the young) have not travelled to the Soviet Union or present-day Russia even though it is a neighbouring country. But, according to border narratives, those who have visited did not always feel very safe when crossing the Russian border, and that perception persists today. Interaction between Russians and Finns obviously lessens the sense of fear mutually. Nevertheless, in the border narratives of elderly Finns, Russians still represent something alien: they are not trusted to buy land and settle permanently in 
Finland. Wartime experiences, heard stories of the war, and a strong emotion of fear, dominate their expressed attitudes towards Russia and the Russians. Among elderly border people, Finnish border guards are thought to be important in assuring both national and, in addition, local security, and they are appreciated and highly trusted.

Sparsely populated borderlands also hold special fears in regard to predators. These fears represent the remote location of borderlands, but the inhabitants' fear of predators in daily life differs from that of other people - the fear of having bears or wolves intrude into the home backyard is not so widely shared with other Finns, and in public discussions and the media, people in cities do not always seem to understand the border people's negative attitudes towards such animals. The fear of the eastern neighbours and the issues of the FinnishRussian border, however, are much more commonly understood and shared.

\section{ACKNOWLEDGEMENTS}

This research was supported by the project Writing Cultures and Traditions at Borders (SA131578).

\section{NOTES}

1 Finland has a borderline between its neighbouring states of Russia, Sweden and Norway.

2 Oral history sources include both oral narratives and their transcriptions, and oral history based texts (Fingerroos \& Haanpää 2006: 9).

${ }^{3}$ Living in the Borderlands collection. The collection is archived at the Joensuu Folklore Archives of the Finnish Literature Society, in Joensuu.

4 The period of the writing collection was April 1 - September 30, 2010. See web pages of Writing Cultures and Traditions at Borders, project: http://www.uef.fi/wctb, last accessed on November 22, 2012.

5 Especially the Folklore Archives at the Finnish Literature Society: http://www.finlit. fi/english/kra/index.htm.

${ }^{6}$ See the writing invitation on the Finnish Literature Society's web-page: http://www. finlit.fi/kra/keruut/raja.pdf, last accessed on November 22, 2012.

7 The remainder of the texts deal with borders between Finland and Sweden, Finland and Norway, and the sea frontier between Finland and Estonia. 
8 More on the Karelia issues can be found, e.g., in: Kinnunen \& Kivimäki 2006; Fingerroos 2010; Fingerroos \& Loipponen 2007; Raninen-Siiskonen 1999.

9 The period of 1968-1982 in Europe is called the time of Finlandisation. During that period the Soviet Union controlled Finland's domestic policy (see Kurki 2012 in this theme issue).

\section{MANUSCRIPT SOURCES}

Living in the Borderlands [Rajaseudun elämää] writing collection, 2010. The collection is archived at the Joensuu Folklore Archives of the Finnish Literature Society, marked by SKS, JPA, and Rajaseutu, pp. 1-261.

\section{REFERENCES}

Aarelaid-Tart, Aili 2006. Cultural Trauma and Life Stories. Helsinki: Kikimora Publications.

Apo, Satu 1997. The Forest in the Finnish Mind. In: Martti Torkkomäki (ed.) Minun Suomeni. [My Finland.] Helsinki: WSOY, pp. 46-49.

Baldwin, David A. 1997. The concept of security. Review of International Studies, Vol. 23, pp. 5-26, doi:10.1017/S0260210597000053.

Bamberg, Michael \& Andrews, Molly (eds.) 2004. Considering Counter-Narratives: Narrating, Resisting, Making Sense. Amsterdam \& Philadelphia: John Benjamins.

Bauman, Zygmunt 2006. Liquid Fear. Cambridge: Polity Press.

Bornat, Joanna 2002. Reminiscence and Oral History: Comparisons Across Parallel Universes. In: Jeffrey Dean Webster (ed.) Critical Advances in Reminiscence Work: From Theory to Application. New York: Springer Publishing Company, pp. 33-43.

Bourke, Joanna 2005. Fear. A Cultural History. London: Virago.

Brednikova, Olga 2000. From Soviet 'Iron Curtain' to 'Post-Soviet Window to Europe': Discursive Reproduction of the Russian-Finnish Border. In: Pirkko-Liisa Ahponen \& Pirjo Jukarainen (eds.) Tearing Down The Curtain, Opening the Gates. Northern Boundaries in Change. Jyväskylä: SoPhi, pp. 25-37.

Doevenspeck, Martin 2011. Constructing the border below: Narratives from the Congolese-Rwandan state boundary. Political Geography 30, pp. 129-142, doi:10.1016/j. polgeo.2011.03.003.

Fingerroos, Outi 2010. Karjala utopiana. [Karelia as an Utopia.] Jyväskylä: Jyväskylän yliopisto.

Fingerroos, Outi 2012. Karjalan kysymyksen kolme aaltoa. [The Three Waves of the Karelia Issue.] In: Outi Fingerroos \& Maunu Häyrynen (eds.) Takaisin Karjalaan. [Returning to Karelia.] Helsinki: SKS, pp. 23-45.

Fingerroos, Outi \& Haanpää, Riina 2006. Muistitietotutkimuksen ydinkysymyksiä. [Central Issues in Oral History Research.] In: Outi Fingerroos \& Riina Haanpää \& Anne Heimo \& Ulla-Maija Peltonen (eds.) Muistitietotutkimus. Metodologisia 
kysymyksï̈. [Oral History Research. Methodological Issues.] Tietolipas, Vol. 214. Helsinki: SKS, pp. 25-48.

Fingerroos, Outi \& Loipponen, Jaana (eds.) 2007. Nykytulkintojen Karjala. [Today's Interpretations of Karelia.] Jyväskylä: Jyväskylän yliopisto.

Furedi, Frank 1997. Culture of Fear. Risk-taking and the Morality of Low Expectation. London: Cassel.

Hakamies, Pekka 2012. Karjala venäläisin silmin. Neuvostoasukkaat luovutetussa Karjalassa. [Karelia in the Eyes of the Russians. Soviet Residents in the Annexed Karelia.] In: Outi Fingerroos \& Maunu Häyrynen (eds.) Takaisin Karjalaan. [Returning to Karelia.] Helsinki: SKS, pp. 75-104.

Häyrynen, Maunu (ed.) 2006. Theme number: Rajoja tilassa ja ajassa. [Theme number: Borders in Space and Time.] Alue ja Ympäristö, No. 2.

Heimo, Anne 2006. Places Lost, Memories Regained. Narrating the 1918 Finnish Civil War in Sammatti. In: Annikki Kaivola-Bregenhøj \& Barbro Klein \& Ulf Palmenfelt (eds.) Narrating, Doing, Experiencing. Nordic Folkloristic Perspectives. Studia Fennica: Folkloristica, Vol. 16. Helsinki: SKS, pp. 47-63.

Hicks, Emily 1993. The Broken Line. In: Massumi, Brian (ed.) The Politics of Everyday Fear. Minneapolis \& London: University of Minnesota Press, pp. 39-40.

Howarth, Ken 1999. Oral History. Stroud: Sutton Publishing Ltd.

Jaago, Tiiu 2006. What Actually Happened in Estonian Political History - Stories of the 20th Century Events from the Viewpoint of Popular Narrated History. Elore, Vol. 13, No. 1, pp. 1-23, http://www.elore.fi/arkisto/1_06/jaa1_06.pdf, last accessed on November 22, 2012.

Kaivola-Bregenhøj, Annikki 2003. The Narrator's Emotions. In: Lotte Tarkka (ed.) Dynamics of Tradition. Perspectives on Oral Poetry and Folk Belief. Studia Fennica: Folkloristica, Vol. 13. Helsinki: Finnish Literature Society, pp. 329-342.

Kangaspuro, Markku 2012. Salaista kaupankäyntiä Karjalalla. [Secret Trade of Karelia.] In: Outi Fingerroos \& Maunu Häyrynen (eds.) Takaisin Karjalaan. [Returning to Karelia.] Helsinki: SKS, pp. 50-72.

Karemaa, Outi 1998. Vihollisia, vainoojia, syöpäläisiä: Venäläisviha Suomessa 19171923. [Enemies, Oppressors and Vermin: Russophobia in Finland 1917-1923.] Helsinki: Suomen Historiallinen Seura.

Karjalainen: Rajavartijat jo korvaamattomia. [The Border Guards are Invaluable.] Editorial by the chief editor. Karjalainen [newspaper], January 4, 2012, p. 2.

Kensinger, Elizabeth A. \& Schacter, Daniel L. 2010. Memory and Emotion. In: Michael Lewis \& Jeannette M. Haviland-Jones \& Lisa Feldman Barret (eds.) Handbook of Emotions. Third Edition. New York: The Guilford Press, pp. 601-617.

Kinnunen, Tiina \& Jokisipilä, Markku 2012. Shifting Images of "Our Wars": Finnish Memory Culture of World War II. In: Tiina Kinnunen \& Ville Kivimäki (eds.) Finland in World War II: History, Memory, Interpretations. History of warfare, Vol. 69. Leiden \& Boston: Brill, pp. 435-482, doi:10.1163/9789004214330_012.

Kinnunen, Tiina \& Kivimäki, Ville (eds.) 2006. Ihminen sodassa. Suomalaisten kokemuksia talvi-ja jatkosodasta. [Human in War. Finns' Experiences of the Winter and Continuation Wars.] Helsinki: Minerva.

Klein, Barbro 2006. Introduction. Telling, Doing, Experiencing. Folkloristic Perspectives on Narrative Analysis. In: Annikki Kaivola-Bregenhøj \& Barbro Klein \& Ulf Pal- 
menfelt (eds.) Narrating, Doing, Experiencing. Nordic Folkloristic Perspectives. Studia Fennica: Folkloristica, Vol. 16, Helsinki: SKS, FLS, pp. 6-28.

Klemettinen, Pasi 2002. Kurkistuksia karhun kulttuurihistoriaan. [Glimpses into the Cultural History of the Bear.] In: Henni Ilomäki \& Outi Lauhakangas (eds.) Eläin ihmisen mielenmaisemassa. [Animal in Human Mind.] Helsinki: SKS, pp. 134-173.

Koskela, Hille 1999. Fear, Control \& Space: Geographies of Gender, Fear of Violence, and Video Surveillance. Publicationes Instituti Geographici Universitas Helsingiensis, A 137. Helsinki: University of Helsinki.

Kosonen, Matti \& Pohjonen, Juha 1994. Isänmaan portinvartijat. Suomen rajojen vartiointi 1918-1994. [The Gatekeepers of the Fatherland: Finland's Border Guarding in 1918-1994.] Helsinki: Otava.

Lähteenmäki, Maria 2009. Maailmojen rajalla. Kannaksen rajamaa ja poliittiset murtumat 1911-1944. [Between the Worlds: Everyday Life and Political Breakdowns in the Finnish-Russian Border Region from 1911 to 1944.] Historiallisia tutkimuksia, Vol. 243. Helsinki: SKS.

Laine, Antti 1999. Finland-Russia, the Border Unites, the Border Divides. In: Finland. The Northern Experience, New Europe and the Next Millennium. Europe in the New Millennium. Helsinki: Tammi Publishers, pp. 152-157.

Latvala, Pauliina \& Laurén, Kirsi 2012. The Sensitive Interpretation of Emotions: Methodological Perspectives on Studying Meanings in Written Life-Historical Narratives. The Retrospective Methods Network. RMN Newsletter, No. 4. Approaching Methodology: A Special Issue of RMN Newsletter, University of Helsinki, pp. 126-136.

Luostarinen, Heikki 1986. Perivihollinen. Suomen oikeistolehdistön Neuvostoliittoa koskeva viholliskuva sodassa 1941-44: tausta ja sisältö. [The Archenemy: The Image of the Soviet Enemy in Right-Wing Press in 1941-1944: Background and Content.] Tampere: Vastapaino.

Massey, Doreen 1994. Space, Place and Gender. Oxford: Blackwell Publishers Ltd.

Massey, Doreen 1995. The conceptualization of place. In: D. Massey \& P. Jess (eds.) A Place in the World? Places, Cultures and Globalization. The Shape of the World. Explorations in Human Geography. Oxford: The Open University \& Oxford University Press, pp. 45-85.

Massumi, Brian 1993. Everywhere You Want to Be: Introduction to Fear. In: Massumi, Brian (ed.) The Politics of Everyday Fear. Minneapolis: University of Minnesota Press, pp. 3-37.

Meinander, Henrik 2012. Finland and the Great Powers in World War II. Ideologies, Geopolitics, Diplomacy. In: Tiina Kinnunen \& Ville Kivimäki (eds.) Finland in World War II. History, Memory, Interpretations. History of warfare, Vol. 69. Leiden \& Boston: Brill, pp. 49-91, doi:10.1163/9789004214330_003.

Misztal, Barbara A. 2003. Theories of Social Remembering. Philadelphia: Open University Press.

Moisio, Sami \& Harle, Vilho 2002. Karhu poliittis-maantieteellisenä naapurina: kansallinen identiteettiprojekti 2000-luvun Suomessa. [The Bear as a Political Geographical Neighbour: The National Identity Project in Twenty First Century Finland.] Turku: Department of Geography, University of Turku. 
Paasi, Anssi 2000. The Finnish-Russian border as a shifting discourse. Boundaries in the world of de- and re-territorialisation. In: Pirkko-Liisa Ahponen \& Pirjo Jukarainen (eds.) Tearing Down the Curtain, Opening the Gates. Northern Boundaries in Change. University of Jyväskylä: SoPhi, pp. 85-100.

Pain, Rachel \& Smith, Susan J. 2008. Fear: Critical Geopolitics and Everyday Life. In: Rachel Pain \& Susan J. Smith (eds.) Fear: Critical Geopolitics and Everyday Life. Aldershot: Ashgate, pp. 1-19.

Palviainen, Simo 2000. Suurpedot Pohjois-Karjalassa. Pohjoiskarjalaisten luonnonkäyttäjien kokemuksia suurpedoista. - Large terrestrial carnivores in North Karelia. Experiences of North-Karelian nature-users concerning large terrestrial carnivores. Regional Council of North Karelia, Vol. 51. Joensuu: Pohjois-Karjalan liitto.

Pickering, Sharon 2006. Border Narratives. From talking security to performing borderlands. In: Borders, Mobility and Technologies in Control. Springer, pp. 45-62, doi: 10.1007/1-4020-4899-8_3.

Pohjonen, Juha 2009. Rajarauhaa Suomen ja Euroopan puolesta. Rajavartiolaitos 19912009. [Peace at Borders - for Finland and Europe: Border Guards in 1991-2009.] Helsinki: Otava.

Portelli, Alessandro 1994. The Text and the Voice. Writing, Speaking, and Democracy in American Literature. New York: Columbia University Press.

Portelli, Alessandro 2003. The Order Has Been Carried Out: History, Memory and Meaning of a Nazi Massacre in Rome. New York: Palgrave Macmillan.

Portelli, Alessandro 2006. Mikä tekee muistitietotutkimuksesta erityisen? [What Makes Oral History Special?] In: Outi Fingerroos \& Riina Haanpää \& Anne Heimo \& Ulla-Maija Peltonen (eds.) Muistitietotutkimus. Metodologisia kysymyksiä. [Oral History Research: Methodological Issues.] Tietolipas, Vol. 214. Helsinki: SKS, pp. 49-64.

Prokkola, Eeva-Kaisa 2009. Unfixing Borderland Identity: Border Performances and Narratives in the Construction of Self. Journal of Borderlands Studies, Vol. 24. No. 3, pp. 21-37, doi:10.1080/08865655.2009.9695737.

Rainio, Minna 2009. "It Was So Sacred": The Finnish-Russian Border Imagined and Constructed in the Stories of Border Area Inhabitants. In: Jopi Nyman (ed.) PostNational Enquiries: Essays on Ethnic and Racial Border Crossings. Newcastle upon Tyne: Cambridge Scholars Publishing, pp. 128-146.

Raittila, Pentti 2011. Venäjä kansalaismielipiteissä. [Russia in Civic Thought.] In: Lotta Lounasmeri (ed.) Näin naapurista: Median ja kansalaisten Venäjä-kuvat. [From the Neighbourhood: Russia in the Images of Media and Citizens.] Tampere: Vastapaino, pp. 125-170.

Raninen-Siiskonen, Tarja 1999. Vieraana omalla maalla. Tutkimus karjalaisen siirtoväen muistelukerronnasta. [As a Stranger on One's Own Ground. Research of the Karelian Occupants' Oral History.] Helsinki: SKS.

Rannikko, Pertti \& Hiedanpää, Juha \& Pellikka, Jani \& Ratamäki, Outi \& Härkönen, Sauli \& Salmi, Pekka 2011. Kohtaamisia metsässä. Eläinkiistoista yhteistoimintaan. [Encounterings in Forest: From the Animal Rows to Cooperation.] Helsinki: Metsäkustannus. 
Relph, Edward 1996. Place. In: Ian Douglas \& Richard J. Huggett \& Mike Robinson (eds.) Companion Encyclopedia of Geography. The Environment and Humankind. London \& New York: Routledge, pp. 906-921.

Rose, Gillian 1995. Place and identity: A sense of place. In: D. Massey \& P. Jess (eds.) A Place in the World? Places, Cultures and Globalization. The Shape of the World. Explorations in Human Geography. Oxford: The Open University \& Oxford University Press pp. 87-132.

Rosenthal, Gabriele 2007 [2004, doi: 10.4135/9781848608191]. Biographical Research. In: Clive Seale \& Giampietro Gobo \& Jaber F. Gubrium \& David Silverman (eds.) Qualitative Research Practice. Concise Paperback Edition. London \& Thousand Oaks \& New Dehli: Sage, pp. 48-64.

Sarmela, Matti 2006. The Bear in the Finnish Environment. Discontinuity and Cultural Existence. Helsinki. http://www.kotikone.fi/matti.sarmela/bear.html, last accessed on November 26, 2012.

Taloussanomat [newspaper]. http://www.taloussanomat.fi/kotimaa/2011/08/21/ess-venalaisten-maakaupat-nousussa/201111653/12, last accessed on November 26, 2012.

Tarkka, Jukka 2012: Karhun kainalossa. Suomen kylmä sota 1947-1990. [Under the Arm of the Bear. Finland's Cold War in 1947-1990.] Helsinki: Kustannusosakeyhtiö Otava.

The Finnish Border Guard. http://www.raja.fi, last accessed on November 26, 2012. Tuan, Yi-fu 1980. Landscapes of Fear. Oxford: Blackwell.

Turunen, Kari E. 2004. Tunne-elämä. [Emotional Life.] Jyväskylä: Atena-Kustannus Oy.

Vilkuna, Kustaa H.J. 2005. Viha: Perikato, katkeruus ja kertomus isostavihasta. [Hate: Armageddon, Bitterness and the Story of the Nordic War.] Helsinki: SKS. 